\title{
WPŁYW WITAMINY D NA PRZEBIEG CIĄŻY ORAZ ZDROWIE MATKI I DZIECKA
}

\section{THE INFLUENCE OF THE VITAMIN D DURING PREGNANCY AND IN MATERNAL AND CHILD HEALTH}

\section{Kamila Bołtuć}

Wydział Lekarski i Nauk o Zdrowiu, Uniwersytet Jana Kochanowskiego w Kielcach

DOI: https://doi.org/10.20883/ppnoz.2019.71

\section{STRESZCZENIE}

Receptory dla witaminy D zlokalizowano w większości tkanek i komórek organizmu, co pozwala przypuszczać, że poziom witaminy D w trakcie ciąży może rzutować na jej przebieg, organogenezę płodu oraz zdrowie kobiety i jej dziecka. Nie wszystkie mechanizmy zostały do końca poznane, jednak badania przeprowadzone w ostatnich latach wykazały, że u kobiet z hipowitaminozą D w trakcie ciąży częściej dochodziło m.in. do poronień i preeklampsji. Dla płodu zagrożenie stanowi zaburzony przebieg organogenezy. Zauważono również w dalszym rozwoju dzieci tendencję do występowania zaburzeń kostnych, częstszych infekcji dróg oddechowych oraz chorób autoimmunologicznych. Biorąc to pod uwagę, należy pamiętać o konieczności suplementacji witaminy D w trakcie ciąży.

Słowa kluczowe: organogeneza, suplementacja, zaburzenia rozwoju, homeostaza wapniowo-fosforanowa, metabolizm.

\section{ABSTRACT}

Receptors for vitamin D are located in almost every tissue and cell of the body. That suggests that vitamin $D$ levels during pregnancy may affect its course, fetal organogenesis and general health of woman and her child. Not all of the mechanisms have been fully understood, however, recent studies have shown that women that suffer from hypovitaminosis D during pregnancy are more susceptible to have miscarriages and preeclampsia. Most importantly he fetus is endangered by disturbed organogenesis. Moreover, children are more exposed to bone disorders, respiratory tract infections and autoimmune diseases in the future. Taking it into account, vitamin $\mathrm{D}$ supplementation is highly recommended during pregnancy.

Keywords: organogenesis, supplementation, disorders of development, calcium and phosphate homeostasis, metabolism.

\section{Wstęp}

Witamina $D(25(\mathrm{OH}) \mathrm{D})$ jest to grupa rozpuszczalnych w tłuszczach steroli, które występują w wielu formach [1]. Dwa najważniejsze z nich to ergokalcyferol (witamina $D_{2}$ ) wytwarzany przez rośliny oraz cholekalcyferol (witamina $D_{3}$ ) wytwarzany w głównej mierze przez organizmy zwierzęce. Dodatkowym źródłem witaminy $\mathrm{D}_{3}$ dla człowieka mogą być produkty spożywcze, m.in. tłuszcze pochodzące z ryb (takich jak łosoś, śledź i makrela) bądź żółtek jaj, zaś witamina $D_{2}$ jest głównie pozyskiwana z roślin oraz grzybów $[2,3]$.

Synteza de novo witaminy $D_{3}$ u ludzi rozpoczyna się w skórze pod wpływem promieniowania UV-B o długości fali 290-315 nm, którego głównym źródłem jest światło słoneczne. Dochodzi wówczas do przemiany 7-dehydrocholesterolu w prewitaminę $\mathrm{D}_{3}$, która przekształcana jest $w$ cholekalcyferol [4]. Ten proces może być osłabiony a nawet hamowany przez używanie kremów przeciwsło- necznych z filtrem ochronnym $\geq 8$, noszenie okularów lub ubrań zakrywających skórę, w porze zimowej, kiedy jest niższy kąt padania promieni słonecznych, a także u ludzi o ciemnej karnacji i osób starszych [2]. Cholekalcyferol jest jednak biologicznie nieaktywny i wymaga przejścia przez dwa etapy metaboliczne zanim stanie się fizjologicznie czynny. Po połączeniu z białkiem wiążącym witaminę $\mathrm{D}_{3}(\mathrm{VDBP}$, ang: Vitamin $D$ binding protein) jest on transportowany do wątroby. Tam pod wpływem enzymu 25-hydroksylazy ulega transformacji do 25-hydroksywitaminy $D_{3}$ czyli $25(\mathrm{OH})$ $D_{3}$ i uwalniany jest do krwiobiegu [5]. Następnie w nerkach ulega hydroksylacji z udziałem enzymu 1- $\alpha$-hydroksylazy do aktywnej formy 1- $\alpha$-25-dihydroksycholekacyferolu (1,25(O$\mathrm{H}_{2} \mathrm{D}_{3}$ ), czyli kalcytriolu $[4,6]$. Metabolizm witaminy $\mathrm{D}_{2}$ przebiega analogicznie. Pod wpływem promieniowania UV-B ergosterol (prowitamina $D_{2}$ ) przekształcany jest do ergokalcyferolu, który jest uwalniany do krwi. Następnie podlega transformacji kolejno w wątrobie i w nerkach do aktywnej 
formy $1,25(\mathrm{OH})_{2} \mathrm{D}_{2}$, która ma trzykrotnie mniejszą aktywność w porównaniu do $1,25(\mathrm{OH})_{2} \mathrm{D}_{3}$. Termin witamina $\mathrm{D}$ (25(OH)D) użyty w dalszej części artykułu odnosi się do obu form [6].

Witamina $\mathrm{D}$ aktywnie uczestniczy w gospodarce wapniowo-fosforanowej. Jednak receptory dla witaminy $D$ (VDR, ang: Vitamin D receptor) występują nie tylko w narządach uczestniczących w regulacji wapnia i fosforu, czyli w kościach, jelicie cienkim oraz nerkach, ale także w wielu innych tkankach i komórkach organizmu (m.in. w tkance nerwowej, komórkach $\beta$ trzustki, oskrzeli, komórkach śródbłonka naczyniowego i keratynocytach) [7, 8]. VDR są także obecne w komórkach zrębu endometrium, przez co witamina D wpływa na proces implantacji zarodka [7].

Klasyczna triada działania aktywnej formy witaminy D polega na wzroście absorpcji jonów wapnia i fosforu w przewodzie pokarmowym, a także wzroście reabsorpcji wapnia z nerek oraz z kości. Pozwala to na utrzymanie w odpowiednim stężeniu we krwi jonów wapnia (normokalcemii), a w konsekwencji poziomu parathormonu (PTH). PTH jest hormonem wytwarzanym przez przytarczyce i uwalnianym do krwiobiegu przy niskich stężeniach wapnia (hipokalcemii), co z kolei jest stymulatorem do zwiększonej produkcji w nerkach kalcytriolu. Witamina D wykazuje szereg innych plejotropowych aktywności: osłabia insulinooporność, obniża aktywność angiotensyny II oraz wpływa na proliferację i różnicowanie komórek naskórka, komórek śródbłonka naczyniowego, komórek układu immunologicznego, a także osteoblastów i chondrocytów. Wpływ witaminy D na układ odpornościowy polega na wzmacnianiu odporności, gdyż ma ona wpływ na proliferację limfocytów T i B oraz produkowanych przez nich cytokin $[6,8]$.

\section{Zakres referencyjny dla witaminy D}

Zakres wartości referencyjnych dla witaminy $D$ wynosi 70-250 nmol/L (28-100 ng/ml). Hipowitaminoza D i jej znaczący niedobór występują przy stężeniu we krwi odpowiednio $25-70 \mathrm{nmol} / \mathrm{L}(10-28 \mathrm{ng} / \mathrm{ml})$ oraz $0-25 \mathrm{nmol} / \mathrm{L}$ (0-10 ng/ml) [9].

\section{Czy istnieje toksyczna dawka witaminy $D$ ?}

Ocenia się, że stężenie witaminy D do $250 \mathrm{nmol} / \mathrm{L}(100 \mathrm{ng} / \mathrm{ml})$ jest bezpieczne zarówno dla dzieci, jak i dla dorosłych, z wyjątkiem osób z nadwrażliwością na tę witaminę. Do nich zalicza się osoby z idiopatyczną hiperkalcemią niemowląt, z zespołem Williamsa, a także niektórymi chłoniakami. Towarzystwa Endokrynologiczne oceniają występowanie toksycznych dawek witaminy $D$ jako rzadkość. Do wystąpienia szkodliwych efektów witaminy $D$ jej stężenie musi przekraczać 375 nmol/L (150 ng/ml). Pierwszym objawem hiperwitaminozy D w organizmie jest zwiększone wydalanie wapnia z moczem (hiperkalcuria), zwiększone stężenie wapnia (hiperkalcemia) oraz fosforu (hiperfosfatemia) we krwi. Nadmiar wapnia może odkładać się w tkankach miękkich m.in. nerek, co skutkuje nefrokalcynozą z potencjalnymi zaburzeniami ich funkcji oraz może prowadzić do skurczu naczyń, przyczyniającego się do wystąpienia nadciśnienia tętniczego [10].

W ocenie większości badaczy witamina $D$ jest jedną z najmniej toksycznych witamin rozpuszczalnych $w$ tłuszczach, co zapewnia bezpieczeństwo jej stosowania. Należy jednak pamiętać, że istnieje na rynku wiele preparatów dostępnych bez recepty (m.in. suplementów diety) zawierających w swoim składzie witaminę $D$, co doprowadza do używania bez kontroli lekarza i kumulowania jej w organizmie pacjenta [11].

\section{Suplementacja witaminy D}

Sama ekspozycja na światło słoneczne w połączeniu $z$ dietą zawierającą produkty bogate $w$ witaminę $D$ jest niewystarczająca, aby uzyskać i utrzymać we krwi stężenie 25(OH)D w zakresie 70-250 nmol/L (28-100 ng/ml). Dlatego aby uniknąć niedoborów i związanych z nią powikłań, zalecana jest jej suplementacja, szczególnie w odniesieniu do kobiet ciężarnych $[2,10]$. Należy pamiętać, że dawka przyjmowanej witaminy D powinna być zlecona przez lekarza.

Zalecane dzienne dawki witaminy D dla określonych grup wiekowych:

- noworodki i niemowlęta do 1 r.ż. 400-1000 IU/ dzień,

- dzieci od 1 do 8 r.ż. 600-1000 IU/dzień,

- chłopcy od 9 do 18 r.ż. 600-1000 IU/dzień,

- mężczyźni od 19 do 70 r.ż. 1500-2000 IU/dzień,

- mężczyźni po 70 r.ż. 1500-2000 IU/dzień,

- dziewczynki od 9 do 18 r.z. 600-1000 IU/dzień,

- kobiety od 19 do 70 r.ż. 1500-2000 IU/dzień,

- kobiety po 70 r.ż. 1500-2000 IU/dzień,

- kobiety w ciąży od 19 do 50 r.ż. 1500-2000 IU/ dzień $[3,10]$.

Zalecane dawki mogą ulec zmianie m.in. u osób otyłych, u kobiet w ciąży i karmiących piersią, o ciemnej pig mentacji skóry bądź zmniejszonej ekspozycji na światło stoneczne $[3,10,12]$

\section{Wpływ niedoboru witaminy D na przebieg ciąży i zdrowie kobiety}

Badanie przeprowadzone w 2007 r. przez Bodnar i wsp. potwierdza matczyny niedobór witaminy $\mathrm{D}$ w pierwszych tygodniach ciąży jako niezależny czynnik wysokie- 
go ryzyka wystąpienia preeklampsji u kobiety ciężarnej. Preeklampsja, czyli stan przedrzucawkowy, może wystąpić po 20 tygodniu ciąży u kobiet z wysokim ciśnieniem tętniczym krwi $\geq 140 / 90 \mathrm{~mm} \mathrm{Hg}$ oraz białkomoczem ( $\geq 0,3 \mathrm{~g}$ białka $w 24$ godzinnej zbiórce moczu). Etiologia nie została w pełni poznana, ale uważa się, że kluczową rolę odgrywa nieprawidłowe tworzenie łożyska i remodeling matczynych tętnic spiralnych. Może być to następstwem stresu oksydacyjnego i zaburzonej angiogenezy, co skutkuje m.in. skurczem i zmianą w przepuszczalności naczyń oraz koagulopatią. Dowiedziono, że witamina D korzystnie wpływa na angiogenezę oraz na rozwój zarodka na wczesnym etapie ciąży, poprzez regulację genów związanych z jego zagnieżdżeniem. Ponadto może obniżać ciśnienie tętnicze krwi, poprzez wpływ na elastyczność i grubość błony wewnętrznej naczyń. Niedobór witaminy D upośledza wymienione wyżej procesy, które nakładają się na patogenezę preeklampsji, dlatego suplementacja witaminy D we wczesnych etapach ciąży jest ważnym czynnikiem chroniącym zarówno kobietę, jak i płód [13]. Podobne wnioski zostały wysunięte w badaniu z 2014 r., gdzie Lechtermann wraz z wsp. dodatkowo zauważyli zmiany matczynego poziomu witaminy $\mathrm{D}$ w zależności od pory roku, co miało związek z występowaniem u kobiet preeklampsji [14].

Kolejnym zaburzeniem, które może wynikaćz niedoboru witaminy D u kobiety, jest nietolerancja glukozy objawiająca się $\mathrm{w}$ trakcie ciąży. U kobiet ciężarnych suplementujących witaminę D zmniejsza się insulinooporność oraz poprawia się metabolizm glukozy. Witamina D wpływa na enzymy działające na $\beta$ komórki trzustki i przekształcenie proinsuliny w insulinę, co skutkuje wzrostem tego hormonu we krwi. Badania wykazały, że kobiety z deficytem witaminy D w organizmie były w grupie wysokiego ryzyka wystąpienia zaburzeń gospodarki węglowodanowej $[6,7]$

W badaniu z 2009 r. Merewood i wsp. zbadali powiązanie niskiego poziomu witaminy D we krwi matki z koniecznością przeprowadzenia cięcia cesarskiego. Badanie finalnie przeprowadzono na 277 kobietach, z których 210 rodziło drogą naturalną a 67 przez cięcie cesarskie. Przez cięcie cesarskie urodziło $28 \%$ kobiet z poziomem $25(\mathrm{OH}) \mathrm{D}$ poniżej $37,5 \mathrm{nmol} / \mathrm{L}$ oraz $14 \%$ kobiet z poziomem $25(\mathrm{OH})$ D równym bądź wyższym 37,5 nmol/L. Kobiety rodzące przez cięcie cesarskie miały niższą wartość średnią 25(OH) $D$ we krwi od kobiet rodzących siłami natury. Badanie wykazało, że kobiety z niedoborem 25(OH)D poniżej 37,5 $\mathrm{nmol} / \mathrm{L}$ w momencie porodu miały czterokrotnie większą szansę na poród przez cięcie cesarskie niż kobiety bez takiego deficytu [15].

Depresja poporodowa (PPD, z ang: postpartum depression) to stan, który występuje u kobiety w ciągu trzech miesięcy od porodu. Wiąże się z przewlekłym zmęczeniem, przygnębieniem i stanami depresyjnymi. Dodatkowo pogarsza relację matki z nowonarodzonym dzieckiem [16]. Zauważono korelację między hipowitaminozą D u kobiety $w$ trakcie ciąży a zwiększonym ryzykiem wystąpienia u niej PPD [16, 17]. VDR obecne są w wielu obszarach mózgu, m.in. w hipokampie oraz zakręcie obręczy. Są to miejsca, w których dochodzi do zmian dających podłoże depresji. Dodatkowo niedobór tej witaminy może rzutować na hormony (takie jak noradrenalina i dopamina), które powiązywane są z zaburzeniami nastroju. Należy również pamiętać, że odgrywa ona ważną rolę w przewodnictwie nerwowym, neuroimmunomodulacji oraz neuroprotekcji, czyli procesach niezwykle ważnych dla prawidłowego funkcjonowania układu nerwowego [17]. W badaniu z 2015 r. Fu i wsp. zbadali u 213 kobiet z Chin poziom witaminy D w ciągu pierwszych 48 godzin od porodu. Po 3 miesiącach kobiety miały zgłosić się na wizytę kontrolną, podczas której uzupełniały kwestionariusze dotyczące m.in. ich zdrowia psychicznego i fizycznego, jakości życia wystąpienia w przeszłości stanów depresyjnych, karmienia piersią oraz zaobserwowanych zmianach w stylu życia od momentu porodu. Do oceny zastosowano chińską wersję Edynburskiej Skali Depresji Poporodowej (EPDS, $z$ ang. Edinburgh Postnatal Depression Scale). Na podstawie wyników EPDS zaobserwowano, że u 26 kobiet wystąpiła PPD w przeciągu 3 miesięcy od porodu. U nich poziom witaminy $D$ we krwi pobranej po porodzie był znacząco niższy niż u kobiet bez PPD. To badanie potwierdza, że witamina $D$ jest niezależnym ochronnym czynnikiem przed wystąpieniem depresji poporodowej [16].

Badania przeprowadzone na ciężarnych kobietach będących nosicielkami ludzkiego wirusa upośledzenia odporności (HIV, z ang: Human Immunodeficiency Virus) wykazały, że hipowitaminoza $D$ we krwi u matki może sprzyjać transmisji wirusa na dziecko. Dodatkowo jest ona powiązana ze wzrostem zachorowań kobiet na bakteryjną waginozę (BV, z ang: Bacterial Vaginosis) w trakcie ciąży $[6,18]$. BV jest chorobą infekcyjną pochwy, w której dochodzi do zaburzeń w składzie jej fizjologicznej flory. Dodatkowo może wpływać na inne schorzenia ginekologiczne i na przebieg ciąży. Badanie z 2009 r. przeprowadzone przez Bodnar i wsp. potwierdza, że hipowitaminoza D $w$ trakcie pierwszego trymestru sprzyja rozwojowi BV. Do badania zakwalifikowano 469 kobiet, którym do 16 tygodnia ciąży pobrano próbkę krwi w celu określenia stężenia witaminy D oraz zbadano je ginekologicznie. U 41\% kobiet badanie mikrobiologiczne potwierdziło BV, a 52\% z nich miało stężenie $25(\mathrm{OH}) \mathrm{D}<37,5 \mathrm{nmol} / \mathrm{L}$. W grupie ciężarnych, które nie miały BV stężenia 25(OH)D były wyższe. 
Badanie wykazało, że bakteryjna waginoza występowała częściej u kobiet o ciemnej karnacji, niezamężnych, otyłych, palących i z wspótistniejącą hipowitaminozą D [19].

W 2014 r. przeprowadzono badanie sprawdzające, czy niski poziom witaminy $\mathrm{D}$ we krwi kobiety wiąże się z nawracającymi poronieniami poprzez narastającą oporność komórkową i autoimmunologiczną. Badanie przeprowadzono na 133 kobietach z historią nawracających poronień (RPL, z ang: recurrent pregnancy losses), ale bez czynników endokrynologicznych, urologicznych bądź genetycznych, które mogłyby wpływać na otrzymane wyniki. Pacjentki przyjmujące dzienną dawkę witaminy $D$ w wysokości 400 IU zostały wyłączone z badania. Spośród 133 kobiet z RPL, 70 z nich (52,6\%) miało poziom witaminy D w normie ( $\geq 30 \mathrm{ng} / \mathrm{ml})$, zaś $63(47,4 \%)$ poniżej normy $(<30 \mathrm{ng} / \mathrm{ml})$. Ponadto stwierdzono, że poziom przeciwciał przeciwko tyreoperoksydazie (TPO), przeciwciał antyfosfolipidowych (APA) i przeciwciał przeciwjądrowych (ANA) był znacząco wyższy u kobiet z hipowitaminozą D. Badanie dowiodło, że znaczna część kobiet z RPL ma niedobór witaminy D, co przekłada się na układ immunologiczny kobiety. Hipowitaminoza D sprzyja powstawaniu przeciwciał (m.in. APA, ANA i TPO), a tym samym promuje powstawanie innych schorzeń immunologicznych mających wpływ na płodność i utrzymanie ciąży [18].

\section{Zapotrzebowanie na witaminę D w trakcie organogenezy płodu}

Organogeneza to proces trwający od 4 do 10 tygodnia ciąży, w którym dochodzi do różnicowania poszczególnych komórek w określone narządy. Wiele z tych komórek zawiera VDR. Łożysko powstaje w 4 tygodniu ciąży, co pozwala na przechodzenie do krwiobiegu dziecka 25(OH)D. Dodatkowo produkuje ono 1- $\alpha$-hydroksylazę, przez co możliwa jest miejscowa synteza aktywnej postaci witaminy $D$, która po związaniu z VDR na poszczególnych komórkach może stymulować rozwój organów (m.in. serca, wątroby, nerek, mózgu oraz jelit) [2]. Udowodniono, że witamina D w trakcie życia prenatalnego bierze udział w rozwoju szkieletu, tworzeniu szkliwa zębów oraz w ogólnie rozumianym rozwoju płodu [4]. Jest to dowodem na to, że niedobór witaminy D w trakcie ciąży skutkuje zaburzeniami w organogenezie i może rzutować na zdrowie dziecka.

\section{Wpływ niedoboru witaminy $D$ na rozwój dziecka}

Badanie przeprowadzone w 2016 r. przez Miliku i wsp. miato na celu sprawdzenie, czy poziom witaminy D we krwi matki ma wpływ na obwód głowy, długość i masę ciała dziecka oraz na termin porodu. Badaniem objęto 7098 ko- biet, które były w ciąży pojedynczej. U kobiet z poziomem witaminy D we krwi w zakresie 73,8-193,2 nmol/L obwód głowy dziecka przy porodzie był większy niż u kobiet, u których poziom witaminy $D$ był niższy. Podobną korelację zaobserwowano w odniesieniu do długości ciała oraz jego masy. Ponadto stwierdzono, że u kobiet z hipowitaminozą D w drugim trymestrze ciąży rosło ryzyko przedwczesnego porodu. Wyniki potwierdziły, że niski poziom witaminy D we krwi matki przekłada się na mniejszą długość ciała dziecka, zwiększa ryzyko przedwczesnego porodu, a także odpowiada za mniejszą masę urodzeniową noworodka oraz mniejszy obwód jego głowy [20].

Niski poziom witaminy $D$ w trakcie ciąży ma wpływ na tworzący się układ kostny. Powoduje hipokalcemię, co stymuluje przytarczyce do uwalniania parathormonu. PTH wzmaga uwalnianie wapnia z rezerw kostnych, aby utrzymać normokalcemię. Osłabia to proces tworzenia kości, zaś wzmaga jego resorpcję, przez co kości dziecka mogą być bardziej podatne na krzywicę we wczesnym dzieciństwie oraz na osteopenię i osteoporozę $w$ dorosłym życiu $[2,4]$

Badanie przeprowadzone w 2011 r. przez Camargo i wsp. miało na celu ustalenie związku między niskim poziomem witaminy D we krwi matki a obecnością i częstością występowania chorób układu oddechowego u dziecka. Do badania zakwalifikowano 922 noworodków. Wyniki potwierdziły, że noworodki o niższym poziomie witaminy D były bardziej narażone na infekcje dróg oddechowych do 3 miesiąca życia, a w wczesnym dzieciństwie częściej obserwowano u nich fenomeny osłuchowe nad polami płucnymi opisywane jako świsty, które nie były związane z astmą oskrzelową [21].

Należy pamiętać o tym, że hipowitaminoza D skutkuje wzrostem aktywności reniny, angiotensyny II oraz układu renina-angiotensyna-aldosteron (RAA), co sprzyja występowaniu nadciśnienia tętniczego i miażdżycy z nim związanej. Są to czynniki ryzyka wystąpienia w przyszłości chorób sercowo-naczyniowych [2]. Niski poziom witaminy D utrzymujący się w życiu dorosłym może mieć swój udział w patogenezie zastoinowej niewydolności serca [9].

Witamina $D$ ma wpływ również na układ nerwowy. Powiązuje się hipowitaminozę D w trakcie ciąży z ryzykiem wystąpienia w późniejszych latach życia dziecka stwardnienia rozsianego (MS, z ang: multiple sclerosis) [22]. MS jest to przewlekła zapalna choroba, która doprowadza do demielinizacji i neurodegeneracji ośrodkowego układu nerwowego (OUN) [22, 23]. Skutkuje ona wystąpieniem wielu objawów klinicznych (m.in. drżenia, przewlekłego bólu, nadmiernej sztywności kończyn, zaburzenia ruchu i koordynacji), które znacząco pogarszają jakość życia, a nawet mogą doprowadzić do niepełnosprawności [24]. Etiologia 
i patomechanizmy MS nie zostały do końca poznane, jednak zaobserwowano wyraźny wpływ czynników środowiskowych, genetycznych oraz immunologicznych, na skutek których układ odpornościowy za pomocą limfocytów T CD4+ niszczy tkankę nerwową [23, 24]. Obszary chromosomu zajmowane przez geny (locus) odpowiadające za rozwój MS posiadają VDR, przez co witamina D może wpływać na ich aktywność. Dodatkowo działa ona przeciwzapalnie, ponieważ moduluje funkcjonowanie komórek układu odpornościowego. Powoduje ona zmniejszenie wytwarzania cytokin zapalnych, hamowanie różnicowania limfocytów Th1 i Th17 oraz wzrost limfocytów T regulatorowych [25]. Jest to dowodem na to, że jej niedobór może zaburzać powyższe procesy, a w konsekwencji przekładać się na uszkodzenie tkanki nerwowej i rozwój stwardnienia rozsianego.

W badaniu z 2012 r. Sorensen i wsp. zbadali, czy poziom witaminy $\mathrm{D}$ u kobiety ciężarnej może wpływać na rozwinięcie się u dziecka we wczesnych latach życia cukrzycy typu 1. Grupę badawczą stanowiło 109 kobiet, u których dzieci przed 15 rokiem życia wystąpiła cukrzyca typu 1. Grupę kontrolną stanowiło 219 kobiet, u których dzieci nie rozwinęła się cukrzyca typu 1. Zaobserwowano, że średni poziom witaminy $D$ we krwi matek z grupy badawczej był znacząco niższy niż u kobiet z grupy kontrolnej. To pozwala na wysunięcie wniosku, że witamina D w rozwoju chorób autoimmunologicznych ma działanie protekcyjne, a niski jej niski poziom we krwi matki może zwiększyć ryzyko wystąpienia cukrzycy typu 1 we wczesnych latach dziecka [26].

\section{Podsumowanie}

Dzięki obecności swoistych receptorów w wielu komórkach i tkankach organizmu, witamina $D$ bierze czynny udział już w początkowych etapach rozwoju, gdyż odpowiada za ogólny rozwój płodu i jego szkieletu kostnego oraz częściowo determinuje wagę noworodka i obwód jego głowy $[7,8]$.

Niedobór witaminy D we krwi kobiety ciężarnej może skutkować wystąpieniem schorzeń we wczesnym rozwoju dziecka. Do nich zalicza się zaburzenia mineralizacji kostnej skutkującej krzywicą w wieku dziecięcym oraz osteoporozą w wieku dojrzałym, zwiększonym ryzykiem wystąpienia u dziecka infekcji układu oddechowego i chorób autoimmunologicznych oraz nadciśnienia tętniczego wraz z chorobami układu sercowo-naczyniowego włącznie [2, $4,9,20-22,25,26]$.

U kobiet hipowitaminoza D w trakcie ciąży powiązywana jest ze zwiększonym ryzykiem wystąpienia m.in. preeklampsji, poronienia, nietolerancji glukozy, bakteryjnej waginozy, depresji poporodowej oraz wykonania cięcia cesarskiego $[6,7,13,14,16-19]$.

Pomimo że mechanizmy, w których dochodzi do opisanych powyżej zaburzeń, nie zostały jeszcze w pełni poznane i wymagają dalszych badań, to $w$ świetle posiadanej wiedzy witamina $D$ ma wpływ na przebieg ciąży oraz zdrowie matki i dziecka, a jej rozważna suplementacja jest wskazana, zwłaszcza u kobiet ciężarnych.

\section{Oświadczenia}

Oświadczenie dotyczące konfliktu interesów

Autorzy deklarują brak konfliktu interesów.

\section{Źródła finansowania}

Autorzy deklarują brak źródeł finansowania.

\section{Piśmiennictwo}

1. Fried DA, Rhyu J, Odato K, Blunt H, Karagas MR, Gilbert-Diamond D. Maternal and cord blood vitamin D status and childhood infection and allergic disease: a systematic review. Nutr Rev. 2016; 74: 387-410. DOI: 10.1093/nutrit/nuv108.

2. Kaludjerovic J, Vieth R. Relationship between vitamin D during perinatal development and health. J Midwifery Women's Heal 2010; 55: 550-60. DOI: 10.1016/j.jmwh.2010.02.016.

3. Holick MF, Binkley NC, Bischoff-Ferrari HA, Gordon CM, Hanley DA, Heaney RP, et al. Evaluation, Treatment, and Prevention of Vitamin D Deficiency: an Endocrine Society Clinical Practice Guideline. J Clin Endocrinol Metab. 2011; 96: 1911-30. DOI: 10.1210/jc.2011-0385.

4. Wagner CL, Taylor SN, Dawodu A, Johnson DD, Hollis BW. Vitamin $D$ and Its Role During Pregnancy in Attaining Optimal Health of Mother and Fetus. Nutrients. 2012; 4: 208-30. DOI: 10.3390/ nu4030208.

5. Wagner CL, Hollis BW, Kotsa K, Fakhoury H, Karras SN. Vitamin $D$ administration during pregnancy as prevention for pregnancy, neonatal and postnatal complications. Rev Endocr Metab Disord. 2017; 18: 307-22. DOI: 10.1007/s11154017-9414-3.

6. Shin JS, Choi MY, Longtine MS, Nelson DM. Vitamin D effects on pregnancy and the placenta. Placenta. 2010; 31: 1027-34. DOI: 10.1016/j.placenta.2010.08.015.

7. Ji J-L, Muyayalo KP, Zhang Y-H, Hu X-H, Liao A-H. Immunological function of vitamin $D$ during human pregnancy. Am J Reprod Immunol. 2017; 78: e12716. DOI: 10.1111/aji.12716.

8. Khundmiri SJ, Murray RD, Lederer E. PTH and Vitamin D. Compr. Physiol., vol. 6, Hoboken, NJ, USA: John Wiley \& Sons, Inc.; 2016, p. 561-601. DOI: 10.1002/cphy.c140071.

9. Zittermann A, Schleithoff SS, Koerfer R. Vitamin D insufficiency in congestive heart failure: Why and what to do about it? Heart Fail Rev. 2006; 11: 25-33. DOI: 10.1007/s10741006-9190-8.

10. Pludowski P, Holick MF, Grant WB, Konstantynowicz J, Mascarenhas MR, Haq A, et al. Vitamin D supplementation guidelines. J Steroid Biochem Mol Biol. 2018; 175: 125-35. DOI: 10.1016/j.jsbmb.2017.01.021.

11. Dudenkov DV, Yawn BP, Oberhelman SS, Fischer PR, Singh RJ, Cha SS, et al. Changing incidence of serum 25 hydroxyvitamin d values above $50 \mathrm{ng} / \mathrm{mL}$ : A 10 -year population-based study. Mayo Clin Proc. 2015; 90: 577-86 DOI: 10.1016/j.mayocp.2015.02.012.

12. Spiro A, Buttriss JL. Vitamin D. An overview of vitamin D status and intake in Europe. Nutr Bull. 2014; 39: 322-50. DOI: 10.1111/nbu.12108. 
13. Bodnar LM, Catov JM, Simhan HN, Holick MF, Powers RW Roberts JM. Maternal Vitamin D Deficiency Increases the Risk of Preeclampsia. J Clin Endocrinol Metab. 2007; 92: 3517-22. DOI: $10.1210 /$ jc. 2007-0718.

14. Lechtermann C, Hauffa BP, Herrmann R, Schündeln MM, GelIhaus A, Schmidt M, et al. Maternal Vitamin D Status in Preeclampsia: Seasonal Changes Are Not Influenced by Placental Gene Expression of Vitamin D Metabolizing Enzymes. PLoS One. 2014; 9: e105558. DOI: 10.1371/journal.pone. 0105558.

15. Merewood A, Mehta SD, Chen TC, Bauchner H, Holick MF Association between Vitamin D Deficiency and Primary Cesarean Section. J Clin Endocrinol Metab. 2009; 94: 940-5. DOI 10.1210/jc.2008-1217

16. Fu C-W, Liu J-T, Tu W-J, Yang J-Q, Cao Y. Association between serum 25 -hydroxyvitamin $D$ levels measured 24 hours after delivery and postpartum depression. BJOG An Int J Obstet Gynaecol. 2015; 122: 1688-94. DOI: 10.1111/1471-0528.13111.

17. Agarwal S, Kovilam O, Agrawal DK. Vitamin D and its impact on maternal-fetal outcomes in pregnancy: A critical review. 2016; 8398. DOI: 10.1080/10408398.2016.1220915.

18. Ota K, Dambaeva S, Han A-R, Beaman K, Gilman-Sachs A, Kwak-Kim J. Vitamin $D$ deficiency may be a risk factor for recurrent pregnancy losses by increasing cellular immunity and autoimmunity. Hum Reprod. 2014; 29: 208-19. DOI: 10.1093/ humrep/det424.

19. Bodnar LM, Krohn MA, Simhan HN. Maternal Vitamin D Deficiency Is Associated with Bacterial Vaginosis in the First Trimester of Pregnancy. J Nutr. 2009; 139: 1157-61. DOI: $10.3945 /$ jn. 108.103168.

20. Miliku K, Vinkhuyzen A, Blanken LM, McGrath JJ, Eyles DW, Burne $\mathrm{TH}$, et al. Maternal vitamin $\mathrm{D}$ concentrations during pregnancy, fetal growth patterns, and risks of adverse birth outcomes. Am J Clin Nutr. 2016; 103: 1514-22. DOI: 10.3945/ ajcn. 115.123752
21. Camargo CA, Ingham T, Wickens $K$, Thadhani R, Silvers KM Epton MJ, et al. Cord-Blood 25-Hydroxyvitamin D Levels and Risk of Respiratory Infection, Wheezing, and Asthma. Pediatrics. 2011; 127: e180-7. DOI: 10.1542/peds.2010-0442.

22. Ueda P, Rafatnia F, Bäärnhielm M, Fröbom R, Korzunowicz G, Lönnerbro R, et al. Neonatal vitamin D status and risk of multiple sclerosis. Ann Neurol. 2014; 76: 338-46. DOI: 10.1002/ ana. 24210

23. Correale J, Gaitán MI, Ysrraelit MC, Fiol MP. Progressive multiple sclerosis: from pathogenic mechanisms to treatment Brain. 2016; 140: aww258. DOI: 10.1093/brain/aww258.

24. Bishop M, Rumrill PD. Multiple sclerosis: Etiology, symptoms, incidence and prevalence, and implications for community living and employment. Work. 2015; 52: 725-34. DOI: 10.3233/WOR-152200.

25. Rhead B, Bäärnhielm M, Gianfrancesco M, Mok A, Shao X, Quach $\mathrm{H}$, et al. Mendelian randomization shows a causal effect of low vitamin D on multiple sclerosis risk. Neurol Genet. 2016; 2: e97. DOI: 10.1212/NXG.0000000000000097.

26. Sorensen IM, Joner $G$, Jenum PA, Eskild A, Torjesen PA, Stene LC. Maternal Serum Levels of 25-Hydroxy-Vitamin D During Pregnancy and Risk of Type 1 Diabetes in the Offspring. Diabetes. 2012; 61: 175-8. DOI: 10.2337/db11-0875.

Zaakceptowano do edycji: 15.12.2019 Zaakceptowano do publikacji: 15.02.2020

Adres do korespondencji:

Kamila Bołtuć

ul. Emilii Plater 12

20-814 Lublin 